ISBN 978-93-84468-92-7

International Conference on Issues in Education, Literature, Humanities and Social Sciences

(IELHSS-2017)

Kuala Lumpur (Malaysia) Jan. 4-5, 2017

\title{
Problem-based Learning for Independent Learning in Pre-university Students
}

\author{
Thiruchelvam Kandaiah \\ Sultan Idris Education University (Malaysia)
}

\begin{abstract}
The objective of this paper is to demonstrate the capability of PBL in making pre-university students independent learners. Lack of independent learning ability in young university graduates is a cause of high rate of unemployment. A survey using an instrument with Likert scale responses was carried out on 321 pre-university students to gauge their perception of independent learning before and after intervention of PBL. The experimental group was subjected to PBL method while the control group was subjected to routine method in solving mathematics problems. Two behavioral domains, 'treating learning of as an adventure' and 'setting personal goals for learning' were used to research independent learning. The results showed that the PBL method of teaching was effective in making students independent learners.
\end{abstract}

Keywords: PBL, independent learning, pre-university students

\section{Introduction}

The purpose of this paper is to demonstrate how PBL can be adapted to promote independent learning in pre-university. Efforts are taken to make lessons as interesting as possible. Learning through didactic lectures and rote memorization are considered outdated and impedes conceptual understandings in students [2]. Exam oriented system in pre-university colleges force lecturers to provide short notes on important concepts and give drill practices to students to fulfill examination requirements [6]. Such 'spoon-feeding' methods have led to overdependence of students on lectures. When these students proceed to institutions of higher education (IHE) they face an unfamiliar culture in independent learning. The primary role of pre-university colleges is to prepare undergraduates for IHE [9]. Hence, these colleges have the responsibility to prepare students to face the challenges in IHE. The PBL promotes holistic teaching and learning and could be useful in nurturing students to become independent learners. PBL is a teaching method grounded in the ideals of constructivism and studentcentered learning [8]. It also helps in extending student thinking and creativity and encourages active student participation in solving problems [3], [8] and [10].

\section{Routine and PBL Methods}

The routine teaching and learning method describes the standard teaching practice adopted by lecturers in pre-university colleges [7]. The lecturer is the central figure in the process that involves four learning components. The first is the lecture component where the lecturer imparts the basic concepts of a topic as prescribed in the curriculum. In the second students practice solving problems related to what they have learnt in lectures. The students are then given structured practice questions and also past exam questions to be solved at their own time. These practice questions are discussed during tutorial sessions. Lastly, students work on challenging problems on their own to reinforce what they have learnt in lectures and tutorial sessions. This is a 
teacher centered approach where students are passive listeners. Lecturers admit that the routine teaching approach does not encourage students to become independent problem solvers [7].

The PBL method of teaching and learning is adapted for students to listen to lectures and take down notes on the basic concepts. After this the facilitator executes the processes in PBL. In this phase the involvement of the lecturer is minimal. The facilitator gives a short briefing on the segments of PBL and the role of students. Most tasks involved in PBL method are handled by the students. Facilitators take supervisory roles to ensure that all segments of PBL method are observed and adhered to. This is a student centered approach where students are active collaborators in finding solutions to problems. Doubts are cleared independently through discussions with group members and on their own. Students strive to earn and own the knowledge gathered. The segments in PBL method are summarized in Table 1.

TABLE I: Steps in PBL method

\begin{tabular}{|l|l|l|}
\hline Segment & Activity & Note \& action \\
\hline \multirow{3}{*}{2} & Groups formed (orientation) & Group leader facilitates \\
\cline { 2 - 3 } & Setting of ground rules & Group leader facilitates \\
\hline \multirow{4}{*}{3} & Problems presented & Facilitator \\
\cline { 2 - 3 } & Distribution of problems & Group leader \\
\cline { 2 - 3 } & List facts of problems & Individual work \\
\cline { 2 - 3 } & Generate ideas & Individual work \\
\hline \multirow{3}{*}{4} & Gather information & Individual work (own time) \\
\cline { 2 - 3 } & Self-directed learning & Individual work (own time) \\
\cline { 2 - 3 } & Reflection on self-directed learning & Individual work (own time) \\
\cline { 2 - 3 } & Presentation of finding & Group (discussion) \\
\cline { 2 - 3 } & Peer sharing of information & Group (discussion) \\
\cline { 2 - 3 } & Design solution to problem & Group (discussion) \\
\hline 5 & Evaluation of group function & Facilitator \\
\cline { 2 - 3 } & Reflect on experience & Facilitator \\
\hline
\end{tabular}

\section{Methodology}

The objective of this research was to compare the difference in independent learning abilities between preuniversity students in PBL method (X) and routine method (C) of teaching and learning. A sample consisting of 321 students in 26 intact groups was selected from a pre-university college to participate in this research. The groups were randomly allocated to $13 \mathrm{X}$ groups and $13 \mathrm{C}$ groups. $\mathrm{X}$ groups were subject to $\mathrm{PBL}$ method and $\mathrm{C}$ groups used the routine method of teaching and learning. The independent variable in the research was the teaching method and the dependent variable was students' perceptions on independent learning. The intervention was carried out using novel mathematics problems from number systems and series as stimuli. To study students' perceptions on independent learning (IL) two behavioral factors were considered: 'treating learning as an adventure' (LA) and 'setting personal goals for learning mathematics' (SG). The data for students' perceptions on IL were collected using the instrument given in Appendix A.

To facilitate the groups in this research the assistance of four lecturers were sort. The facilitators were given sufficient training and briefing on the PBL procedures to enable them to function efficiently and accurately to ensure validity and reliability of intervention. Mock lessons for the facilitators were held to ensure consistency in classroom practices. Different lesson plans were prepared for facilitators of the $\mathrm{X}$ and $\mathrm{C}$ groups. Facilitators were instructed to adhere to prescribed lesson plans closely to avoid variation in approaches.

The first set of data was collected before intervention using instrument in Appendix A. The intervention of the two teaching methods was carried out by the respective facilitators. During intervention the $\mathrm{X}$ and $\mathrm{C}$ groups were given a similar list of four novel mathematics problems to be solved over one week. The facilitators for the $\mathrm{X}$ groups facilitated and supervised the processes of PBL method while the facilitators for the $\mathrm{C}$ groups carried out routine method of teaching. A second set of data was collected after intervention using the same instrument (Appendix A). The scores for students' perceptions of IL were taken based on students' self-assessment. 
Appendix A consists of eleven items using the Likert's Scale from 1 to 5. Items 1, 2, 3, 6, 8, 9 and 11 were used to analyze LA and items 4, 5, 7 and 10 were used to analyze SG. The data collected were analyzed and used to test three hypotheses on students' perceptions of IL. They are: Ho 1:There is no significant difference in the median of overall score for students' perceptions of IL between the X group and the C method group; Ho 2: There is no significant difference in the median of the score for students' perceptions of 'treating learning as an adventure' between the $\mathrm{X}$ group and the $\mathrm{C}$ group; Ho 3: There is no significant difference in the median of the score for students' perceptions of 'setting personal goals for learning between the $\mathrm{X}$ group and the $\mathrm{C}$ group.

\section{Research Analyses}

Mann-Whitney $\mathrm{U}$ test was used to compare the difference in the median scores between the $\mathrm{X}$ and $\mathrm{C}$ groups in the pre-test and the post-test [4]. The Wilcoson test was used to compare the difference in median scores in the pre-test and the post test for the $\mathrm{X}$ and $\mathrm{C}$ groups. The overall difference in the median scores for $\mathrm{X}$ and $\mathrm{C}$ in IL before and after intervention is given in Table 2 and Table 3. The data was collected for 159 students in $\mathrm{X}$ $(n=159)$ and 162 students in $C(n=162)$. The median scores for IL before intervention indicate that $X$ and $C$ are similar (Median Pre $X=88.00 \&$ Median Pre $C=88.00$ ) with $\mathrm{p}=0.616$ (Table 2). Comparison of median scores after intervention for $\mathrm{X}$ and $\mathrm{C}$ in Table 3 (Median Post $\mathrm{X}=90.0 \&$ Median Post $\mathrm{C}=88.0$ ) indicate that PBL method has a positively significant effect $(p=0.002)$ in improving the students' perception of IL. This outcome is confirmed by the median scores in Table 2 (Median Pre $\mathrm{X}=88.00$, Median Post $\mathrm{X}=90.00 \& p=0.001$ ). Comparison of median scores after intervention for $\mathrm{X}$ and $\mathrm{C}$ have indicated that PBL method group (X) has fared better than the routine group (C) in LA as indicated in Table $2(p=0.003)$. However, the median scores for $\mathrm{SG}$ in the same table showed no positively significant difference $(p=0.557)$.

TABLE II: Comparing the median scores in the analysis independent learning (Mann-Whitney U test)

\begin{tabular}{|c|c|c|c|c|c|}
\hline \multicolumn{6}{|c|}{ median } \\
\hline & & $\mathrm{C}$ & $\mathrm{X}$ & Z - statistic & $\mathrm{p}$-value \\
\hline \multirow[t]{2}{*}{ IL } & pre & $88.00(12)$ & $88.00(12)$ & -0.502 & 0.616 \\
\hline & post & $88.00(14)$ & $90.00(12)$ & -3.066 & 0.002 \\
\hline \multirow[t]{2}{*}{ LA } & pre & $25.00(4)$ & $25.00(4)$ & -0.546 & 0.585 \\
\hline & post & $24.00(4)$ & $26.00(3)$ & -2.930 & 0.003 \\
\hline \multirow[t]{2}{*}{ SG } & pre & $19.00(3)$ & $19.00(4)$ & -0.267 & 0.789 \\
\hline & post & $19.00(3)$ & $19.00(3)$ & -0.587 & 0.557 \\
\hline
\end{tabular}

TABLE III: Comparing the median scores in the analysis for independent learning (Wilcoson test)

\begin{tabular}{|c|c|c|c|c|c|}
\hline \multicolumn{6}{|c|}{ median } \\
\hline & & pre & post & Z - statistic & p-value \\
\hline \multirow[t]{2}{*}{ IL } & $\mathrm{C}$ & $88.00(12)$ & $88.00(14)$ & -0.169 & 0.866 \\
\hline & $X$ & $88.00(12)$ & $90.00(12)$ & -3.387 & 0.001 \\
\hline \multirow[t]{2}{*}{ LA } & $\mathrm{C}$ & $25.00(4)$ & $24.00(4)$ & -0.575 & 0.565 \\
\hline & $X$ & $25.00(4)$ & $26.00(3)$ & -2.301 & 0.021 \\
\hline \multirow[t]{2}{*}{ SG } & $\mathrm{C}$ & $19.00(3)$ & $19.00(3)$ & -0.287 & 0.774 \\
\hline & $X$ & $19.00(4)$ & $19.00(3)$ & -6.00 & 0.549 \\
\hline
\end{tabular}

\section{Conclusion and Discussion}

The analysis of the overall scores in students' perception of IL showed that the PBL method group fared better than the routine method group. For specific components of IL the PBL group did significantly better in LA but there was no difference between the two groups for SG. As such the null hypotheses $\mathrm{H}_{\mathrm{o}} 1$ and $\mathrm{H}_{\mathrm{o}} 2$ were rejected and $\mathrm{H}_{\mathrm{o}} 3$ was not rejected.

These results indicate that PBL method of teaching and learning has helped pre-university college students to become independent learners. A closer look at the analysis of independent learning shows that the PBL method group has developed a greater tendency of considering problem solving as an adventure. However, they showed 
a lesser tendency of being good planners as their scores for goal setting was not better than routine method group. The students in both groups have not realized the relevance and the importance of goal setting.

Learning is not always a straight forward process and very often it is made up of disparities and confusion [5]. However, independent learners are prepared and capable of handling the learning process without much fretting whereas students who are used to close guidance by the teachers will get easily discouraged when they face obstacles in finding solutions to problems on their own [5]. Not all students are natural independent learners. Some students become independent learners based on life circumstances and learning style [1]. Preuniversity college students being matured enough were appreciative of the experience in seeing themselves as independent learners. They cherished the guidance and support given by facilitators and other group members in PBL.

The PBL experience made students treat problem solving exercises as adventures of a different sort. The features considered for the scoring of learning as an adventure includes students' preference to use different methods of solving problems and the satisfaction of solving the problems by themselves. Besides these, PBL students showed willingness to gather as much knowledge as possible and were proactive in considering various sources of learning. They are persistent and don't give up. This finding is consistent with what was found in earlier studies [1]. The process of learning consists of exciting adventures where mistakes are made and thereafter remedies are found. What they learn while solving problems may be termed as mental adventure. Treating problem solving as an adventure is an important component in becoming independent learners. Students who consider the challenges in solving problem as an adventure will not feel learning is a burden at all. They are motivated by setting internal goals to achieve and are driven by their own personal achievement. They evaluate themselves and realize their strengths and weaknesses [1].

Social adventures are something that involves challenges with obstacles and risks. If a person were to be left to overcome the challenges all by himself there is a possibility that he will quit. However, when he is one in a group which is given the challenge he would eventually succeed in overcoming the challenge even if he is weak. He would also realize that he actually has the strength to overcome challenges [1]. This is analogous to the situation where students were given novel mathematics problems to be solved. Novel mathematics problems offered challenges that the students face for the first time. If a good student is given such a problem to solve he would use his inherent ability to solve the problem whereas a weak student will probably give up after a few minutes. When solving problems as a group in PBL the group members were given sufficient guidance by fellow group members on the steps to be taken to solve the problem. When the students work through PBL to solve a problem and make mistakes there is somebody who will point it out and get it corrected. When the group solves one problem and progresses to another it is like progressing from one adventure to another.

This research showed that the scores in goal setting were not high. This indicates that the students did not give much emphasis to goal setting when solving problems. The features considered for scoring of goal setting include the students' attitude towards datelines. It also covers personal satisfaction in what they have learnt and the habit to record successes and failures in solving problems. The students must be made aware of the relevance of goal setting in the learning process. The process of learning to adventure and goal setting are linked [5]. She said that learning is an adventure that can be interrupted when the primary focus of the classroom is on the goal. Though learning is considered an adventure it cannot be like that in a runaway train where students have no idea as to where the adventure is going to end. A set goal will ensure that students do not veer off too much [5]. Making amendments in the practices of PBL method to include and emphasize the need for goal setting would make the students better independent learners. When students realize that the learning process is part of the goal, they will not fear failure anymore [5]. She added that traditional teachers and classrooms make little room for failure as everything is based on grades and exams. In the PBL process the students are afforded ample opportunities to explore the options available to achieve set goals. In PBL failure is not a crime but failing to try is. 


\section{References}

[1] Alpha Omega Academy (2013). 7 Characteristics of Independent Learners. 804 N. 2nd Ave. E. Rock Rapids, IA 51246 $800.682 .7396 \mathrm{http} / / \mathrm{www}$. aoacademy.com/blog/trends-and-tips/7-characteristics-of-independent-learners/ (Retrieved 30/10/2013).

[2] Barab, S. A., Sadler, T. D., Heiselt, C.,Hickey, D. T., \& Zuiker, S. (2007). Relating narrative, inquiry, and inscriptions: Supporting consequential play. Journal of Science Education and Technology, 16, 59-82. https://doi.org/10.1007/s10956-006-9033-3

[3] Cazzola, M. (2008), Problem-Based Learning and Mathematics: Possible Synergical Actions. In L. G'omez Chova, D. Mart' 1 Belenguer, and I. Candel Torres (Editors), ICERI2008.

Proceeding, IATED (International Association of Technology, Education and Development), Valencia, Spain, 2008 (ISBN: 978-84-612-5091-2).

[4] Chua,Y.P. (2012). Mastering research methods. McGraw-Hill Education(M) Sdn Bhd.

[5] De Neen, J. (2013). 10 Reasons Why Educators Should Encourage Independent Learning. http://www.opencolleges.edu.au/informed/news/teachers-or-facilitators-10-reasons-why-educators-should-step-out-ofthe-way-and-encourage-independent- learning/\#ixzz2jFU73WP9 (Retrieved on 30.10.2013)

[6] Kamal, Megat, Sohaida \& Zaimah (2014). Tahap kemahiran pembelajaran kendiri pelajar Kolej Matrikulasi Selangor. Prosiding Seminar Penyelidikan Pendidikan Program Matrikulasi Peringkat Kebangsaan Kali Ke-8 Tahun 2014. Bahagian Matrikulasi, Kementerian Pendidikan Malaysia.

[7] Kandaiah, T. \& Ng C. H. (2014) (In print). Hasrat PPPM 2013-2025 berkaitan kemahiran berfikir aras tinggi dan tanggapan mengenai perlaksanaannya di kalangan pensyarah-pensyarah matematik. Kolej Matrikulasi Perak.

[8] Mac Math, Sheryl; Wallace, John ; Chi, Xiaohong (2009). Problem-Based Learning in Mathematics: A Tool for Developing Students' Conceptual Knowledge. The Literacy and Numeracy Secretariat, Ontario Institute for Studies in Education of the University of Toronto.

[9] MOE (2006). Mathematics QM016 syllabus specification. Matriculation Division, Ministry of Education Malaysia.

[10] Padmavathy R. D. \& Mareesh. K (2013). Effectiveness of Problem Based Learning In Mathematics. International Multidisciplinary e-Journal. ISSN 2277 - 4262. 
Appendix A

\section{Questionnaire}

This questionnaire consists of statements about your level of independence in learning math. There is no right or wrong answers.

Please circle the score that deems fit for each statement.

Additional comments are appreciated.

Score key

$$
\begin{array}{|l|l|l|l|l|}
\hline 1 & 2 & 3 & 4 & 5 \\
\hline
\end{array}
$$

5 - $\quad$ Totally agree with the statement

$4 \quad$ - $\quad$ Agree with the statement

3 - Not very sure

2 - Do not agree

1 - $\quad$ Totally do not agree / Do not concern me

\begin{tabular}{|c|c|c|c|c|c|c|}
\hline No & Statement & \multicolumn{5}{|c|}{ Score } \\
\hline 1 & I would like to learn different ways of solving mathematics problems. & 1 & 2 & 3 & 4 & 5 \\
\hline 2 & I feel happy when I am able to solve a mathematical problem on my own. & 1 & 2 & 3 & 4 & 5 \\
\hline 3 & $\begin{array}{l}\text { I love to learn how mathematics problems are solved and apply it to other } \\
\text { problems. }\end{array}$ & 1 & 2 & 3 & 4 & 5 \\
\hline 4 & I usually set a goal to be achieved by myself. & 1 & 2 & 3 & 4 & 5 \\
\hline 5 & $\begin{array}{l}\text { I keep record of successes and failures to determine my strength and } \\
\text { weaknesses in mathematics problem solving. }\end{array}$ & 1 & 2 & 3 & 4 & 5 \\
\hline 6 & When given a math problem I'll solve it without being prompted by anyone. & 1 & 2 & 3 & 4 & 5 \\
\hline 7 & I think I should learn as much as possible. & 1 & 2 & 3 & 4 & 5 \\
\hline 8 & $\begin{array}{l}\text { I am proactive and willing to pursue additional learning materials from } \\
\text { various sources. }\end{array}$ & 1 & 2 & 3 & 4 & 5 \\
\hline 9 & $\begin{array}{l}\text { In seeking a solution to a problem I will work independently to review } \\
\text { resources other then resources provided by the lecturers. }\end{array}$ & 1 & 2 & 3 & 4 & 5 \\
\hline 10 & I get satisfaction in what and how much I learn. & 1 & 2 & 3 & 4 & 5 \\
\hline 11 & I don't give up. I will work hard to understand a concept before seeking help. & 1 & 2 & 3 & 4 & 5 \\
\hline
\end{tabular}

\section{Additional comments:}

